\title{
Perancangan dan Penerapan Kendali Lampu Ruangan Berbasis IoT (Internet of Things) Android
}

\author{
Wisnu Widi Anggoro ${ }^{1}$, Indrastanti R. Widiasari ${ }^{2}$ \\ ${ }^{1,2}$ Universitas Kristen Satya Wacana; Jl. Diponegoro 52-60, Salatiga 50711, Indonesia, Fax. \\ 321433 \\ ${ }^{3}$ Jurusan Teknik Informatika, FTI UKSW, Salatiga \\ e-mail: ${ }^{1} 672016258 @$ student.uksw.edu, ${ }^{2}$ indrastanti.widiasari@uksw.edu
}

\begin{abstract}
Abstrak
Internet of Things (IoT) adalah sebuah konsep yang bertujuan untuk memperluas manfaat dari konektivitas internet secara terus menerus. Seiring berkembangnya jaman Internet of Things banyak digunakan untuk berbagai macam bidang guna membantu kehidupan manusia, salah satunya adalah perangkat elektronik lampu ruangan yang dapat dikendalikan secara jarak jauh dengan memanfaatkan koneksi internet dan dikendalikan melalui smartphone android. Penelitian ini dilakukan dengan tujuan membangun sebuah prototype kendali rumah pintar (smart home) menggunakan modul NodeMCU ESP8266 sebagai microcontroller dan kontroler sistem dengan menggunakan bot pada aplikasi android Telegram. Berdasarkan hasil uji coba yang dilakukan, dapat disimpulkan bahwa system dapat bekerja dengan baik sesuai dengan tujuan.
\end{abstract}

Kata kunci: Internet of Things, Android, Microcontroller, Smart Home

\begin{abstract}
Internet of Things (IoT) is a concept that aims to expand the benefits of internet connectivity continuously. Along with the development of the era, the Internet of Things is widely used for various fields with the intention to helping human's life, one of them is an electronic device for room lights that can be controlled remotely by utilizing an internet connection and controlled via an android smartphone. This research was conducted with the aim of building a smart home control prototype using the NodeMCU ESP8266 module as a microcontroller and system controller by using a bot on the Telegram, an android application. Based on the results of the experiments that has been done, it can be concluded that the system can work well according to it purpose.
\end{abstract}

Keywords: Internet of Things, Andorid, Microcontroller, Smart Home.

\section{PENDAHULUAN}

Di era saat ini manusia tidak bisa terlepas dengan internet. Internet seakan menjadi kebutuhan yang sangat penting bagi manusia. Tidak dipungkiri juga internet juga membantu banyak pekerjaan manusia. Dengan hadirnya internet manusia dapat bekerja, bertukar data, dan melakukan monitoring dengan hanya lewat control device jarak jauh. Internet seakan menjadi jembatan penghubung berbagai pekerjaan manusia. Peristiwa ini tak lepas dari teknologi IoT (Internet of Things). 
Tidak dipungkiri lagi untuk saat ini smartphone merupakan barang yang wajib dimiliki hampir sebagian manusia di jaman sekarang. Smartphone saat ini telah mempunyai banyak sekali sistem operasi, salah satunya adalah android. Menurut Lembaga Riset digital marketing emarketer memperkirakan pada 2018 jumlah pengguna aktif smartphone di Indonesia lebih dari 100 juta orang. [1]

Di era digital yang semakin maju, android juga mengalami banyak pengembangan dan penambahan fungsi. Selain untuk sarana bertukar informasi dan telekomunikasi, android saat ini telah dapat digunakan sebagai media remote control untuk berbagai alat yang bisa disebut Smart Home. Dengan begitu android dapat mempermudah aktivitas user dalam mengendalikan perangkat elektronik. [2]

Smart home atau rumah pintar adalah sala satu pengembangan atau inovasi dari penerapan internet of things, dimana pada penerapannya hampir semua benda di rumah dapat dikendalikan secara manual dan otomatis dengan bantuan remote.teknologi tersebut dapat memberikan dampak positif untuk rumah sehingga membuat pemilik merasa aman dan nyaman.[3]

Pembangunan fasilitas kendali lampu wireless ini dimaksudkan agar mempermudah user untuk mengontrol perangkat elektronik dan terintergrasi dalam satu sistem. Dengan adanya sistem diharapkan dapat membantu user mengatasi hambatan waktu dan tempat dengan mengendalikan perangkat elektronik seperti lampu secara jarak jauh sehingga lebih efisien dalam melakukan pekerjaan, terutama pada bangunan yang memiliki banyak lantai akan memakan waktu dan tenaga yang lebih besar.

Pada penelitian sebelumnya yang telah dilakukan tentang "Internet of Things (IoT) Sistem Pengendalian Lampu Menggunakan Raspberry Pi Berbasis Mobile" telah mampu menciptakan sebuah system kontrol perangkat lampu dengan menggunakan microcontroller Raspberry Pi dan smartphone android sebagai remote [4]. Pada penelitian lain tentang "Penerapan Internet of Things (IoT) Pada Sistem Kendali Lampu Berbasis Mobile" berisi tentang sebuah penelitian yang menghasilkan sebuah sistem kendali lampu dengan memanfaatkan bahasa pemrograman Phyton dan sebuah aplikasi sebagai kendali perangkat [5]. Penelitian sebelumnya tentang "Implementasi Aplikasi Rumah Pintar Berbasis Android Dengan Arduino Microcontroller" berhasil menciptakan aplikasi kendali rumah pintar dengan menggunakan Arduino Uno sebagai microcontroller dan memanfaatkan Bluetooh sebagai alat penghubung perangkat dan software yang ditanam di microcontroller [6].

Dalam penelitian ini peneliti ingin membangun sistem kendali lampu ruangan berbasis IoT dengan menggunakan smartphone android. Memanfaatkan microcontroller NodeMCU sebagai sistem kendali dan penghubung dengan koneksi jaringan internet. Hal ini dibuat karena proses menghidupkan dan mematikan saklar masih dilakukan dengan cara manual sehingga user harus berjalan menuju saklar. Teknologi ini diharapkan dapat membantu aktivitas sehari-hari dengan lebih menghemat tenaga dan waktu teruntuk jika user sedang melakukan aktivitas lain yang sifatnya tidak dapat ditinggalkan.

\section{METODE PENELITIAN}

\subsection{Kajian Pustaka \\ 2.1.1 Internet of Things (IoT)}

Internet of Things atau biasa disebut IoT adalah sebuah pengembanganyang bertujuan untuk menghubungkan perangkat-perangkat elektronik menjadi sebuah satu kesatuan dan dapat saling bertukar informasi satu sama lain memanfaatkan sebuah jaringan internet sebagai media pengubung.[4]

Dalam sebuah tulisan karya ilmiah McKinsey Global Institude, Internet of Things adalah teknologi dimana kita dapat mengubungkan mesin, perangkat, dan benda fisik dengan sensor jaringan untuk saling bertukar informasi dan mengelola kemampuannya sendiri, sehingga 
dengan adanya sebuah mesin untuk saling bertukar informasi dan bahkan bertindak mandiri berdasarkan informasi yang diterima. Dalam sebuah jurnal ilmiah mengenai Internet of Things mengatakan bahwa Internet of Things adalah sebuah benda memiliki identitas dan dapat mengelola kinerjanya sendiri, bertukar informasi. Bertujuan untuk mempermudah manusia dalam bertukar informasi dengan benda, dan bertukar informasi sesama benda lainnya.[7]

\subsubsection{Android}

Menurut Safaat Nazruddin (2011) Android adalah sebuah pengembangan dari sistem operasi Linux yang ditujukan untuk telepon seluler. Pada dasarnya Android bersifat open source sehingga memberi kesempatan pada pengembang untuk berinovasi menciptakan sebuah aplikasi.[5]

\subsubsection{Ponsel Pintar (Smart Phone)}

Ponsel pintar adalah perkembangan dari telepon genggam dengan penambahan fitur-fitur penunjang selayaknya personal komputer dan juga penambahhan konektivitas tambahan yang dapat diinstall pada perangkat. Untuk segi arsitektur device sudah dibekali dengan inputan seperti QWERTY miniatur keyboard dan touchscreen. [8]

\subsubsection{NodeMCU}

NodeMCU adalah sebuah microcontroller berbentuk board elektronik yang berbasis chip ESP8266 memiliki kemampuan sama seperti mikrokontroler dan juga koneksi internet (WiFi). Terdapat beberapa pin I/O sehingga pengembang dapat memanfaatkan manjadi aplikasi monitoring maupun controlling pada proyek IoT. NodeMCU ESP8266 memiliki kesamaan dengan Arduino sehingga dapat deprogram menggunakan Arduino IDE. Bentuk fisik dari NodeMCU ESP 8266, terdapat port USB (mini USB) sehingga akan memudahkan dalam pemrogramannya. NodeMCU ESP8266 merupakan modul turunan pengembangan dari modul platform IoT (Internet of Things) keluarga ESP8266 tipe ESP-12. Secara fungsi modul ini hampir menyerupai dengan platform modul arduino, tetapi yang membedakan yaitu dikhususkan untuk "Connected to Internet".[9]

\subsubsection{Relay}

Module relay adalah sebuah perangkat yang memanfaatkan elektromagnetik untuk menjalankan saklar. Terdiri dari susunan sederhana lilitan kumparan kawat pada inti besi. Jika kumparan kawat mendapat energy maka medan magnet yang terbentuk dapat menarik amatur berporos sebagai pengungkit saklar (Jaelani Iskandar, St, and Eng 2016).[6]

\subsubsection{Telegram}

Telegram adalah sebuah aplikasi instant messenger berbasis cloud dan layanan VOIP. Telegram dapat dipasang pada perangkat yang menggunakan sistem operasi Android, iOS, Windows phone, macOS, dan Linux. Pengguna dapat saling bertukar pesan, video, audio, hingga berbagai jenis file. Pada dasarnya aplikasi Telegram merupakan aplikasi berbasis open source, akan tetapi untuk kode sumber terbaru pihak internal mengumumkan secara bertahap, sedangkan untuk kode server bersifat close source.[10]

\section{2 Metode Penelitian}

Tahapan yang akan digunakan pada penelitian Perancangan dan Penerapan Kendali Lampu Ruangan Berbasis IoT (Internet of Things) Android menggunakan model SDLC (System Development Life Cycle). 


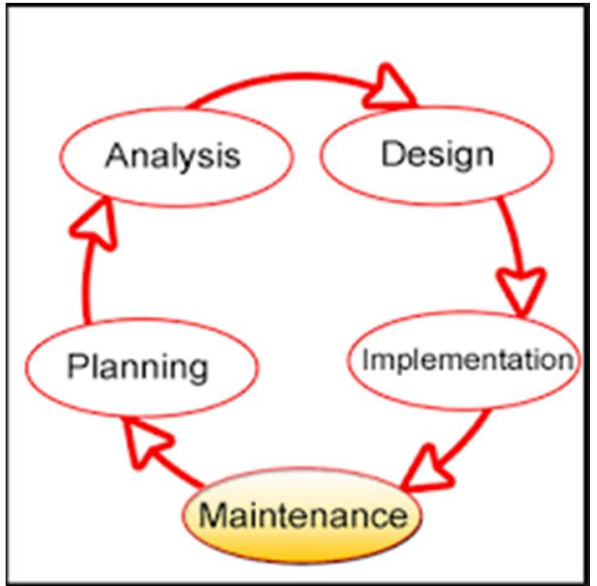

Gambar 1. Tahapan Penelitian

Tahapan pada Gambar 1 dapat dijelaskan sebagai berikut:

a)Tahap perencanaan (Planning) bagaimana rancangan ini dibentuk sesuai dengan permasalahan yang ada dan mengidentifikasi modul apa saja yang akan dibutuhkan dalam penelitian ini.

b) Tahap analisis sistem (Analysis) merupakan tahap penelitian atas permasalahan yang ada. Permasalahan yang ada pada saat ini adalah bagaimana membangun sistem yang dapat membantu dan memudahkan user dapat mengendalikan perangkat elektronik dengan memanfaatkan smartphone yang dimiliki.

c) Tahap perancangan sistem (Design) merupakan tahap untuk menetukan proses tahapan perancangan dengan modul:

- Microcontroller NodeMCU

- Relay 5V 2 chanel

- Kabel jumper female to female

- Kabel listrik

- Lampu LED

- Kabel USB

Pada Gambar 2 berisi tentang rangkaian aplikasi yang dimulai dari aplikasi smartphone, aplikasi smartphone yang dimaksud disini adalah aplikasi bot Telegram yang digunakan sebagai controllerroller yang sebelumnya telah disambungkan dengan microcontroller NodeMCU. Input perintah yang dikirimkan oleh user melalui aplikasi bot kemudian diterima oleh microcontroller. Input yang telah diterima kemudian dibaca dan diteruskan sebagai perintah oleh microcontroller untuk mengendalikan switch relay 2 chanel yang terhubung dengan NodeMCU, kemudian relay akan meneruskan ke perangkat elektronik yang telah dihubungkan dengan relay sebagai hasil akhir untuk menghidupkan/mematikan perangkat lampu.

Berikut Gambar 2 yang berisi dari rangkaian aplikasi kendali perangkat elektronik dan Gambar 3 adalah rangkaian dari microcontroller NodeMCU ke Relay.

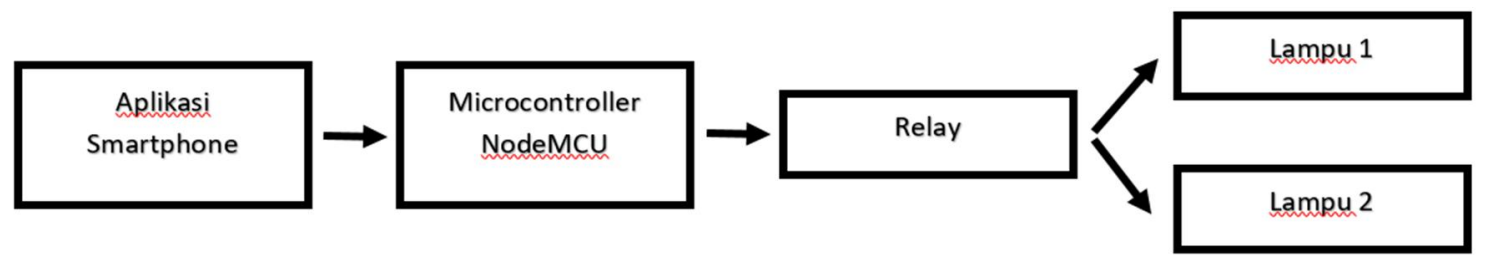

Gambar 2. Rangkaian Aplikasi 


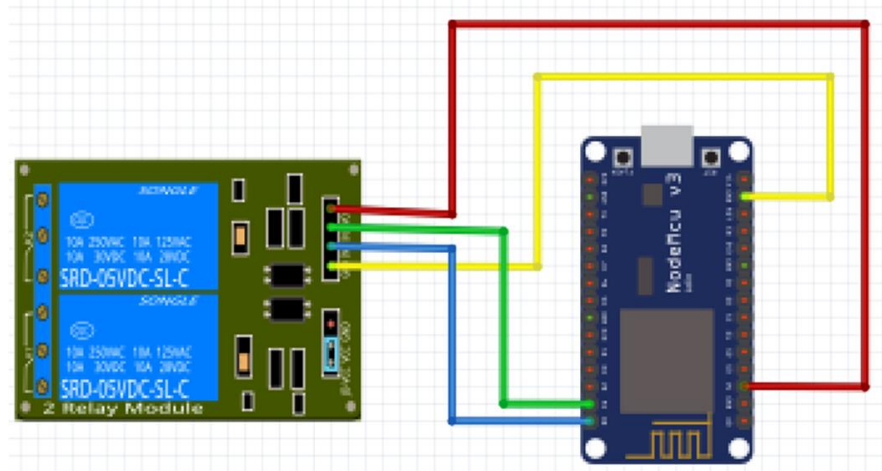

Gambar 3. Rangkaian Microcontroller

Tabel 1. Rangkaian Kabel Jumper

\begin{tabular}{|c|c|c|}
\hline \multicolumn{2}{|c|}{ PORT } & \multirow{2}{*}{ KABEL } \\
\cline { 1 - 2 } NodeMCU & Relay & \\
\hline G & GND & KUNING \\
\hline VU & VCC & MERAH \\
\hline D0 & IN1 & BIRU \\
\hline D1 & IN2 & HIJAU \\
\hline
\end{tabular}

d) Tahap implentasi sistem (Implementation) merupakan tahap untuk melakukan perakitan modul modul yang dihubungkan dengan kabel jumper. Setelah itu peniliti membuat perintah pemrograman yang dilakukan di microcontroller dengan menggunakan aplikasi Arduino IDE. Kemudian dilakukan pembuatan bot di aplikasi Telegram. Setelah sistem dan controller jadi maka perangkat elektronik disambungkan melalui relay selanjutnya dihubungkan dengan sumber listrik.

e) Tahap pemeliharaan sistem (Maintenance) merupakan proses pemeliharaan dan melihat apakah ada kendala atau error selama dijalankan. Sehingga nantinya user nyaman dalam penggunaannya. 


\section{HASIL DAN PEMBAHASAN}

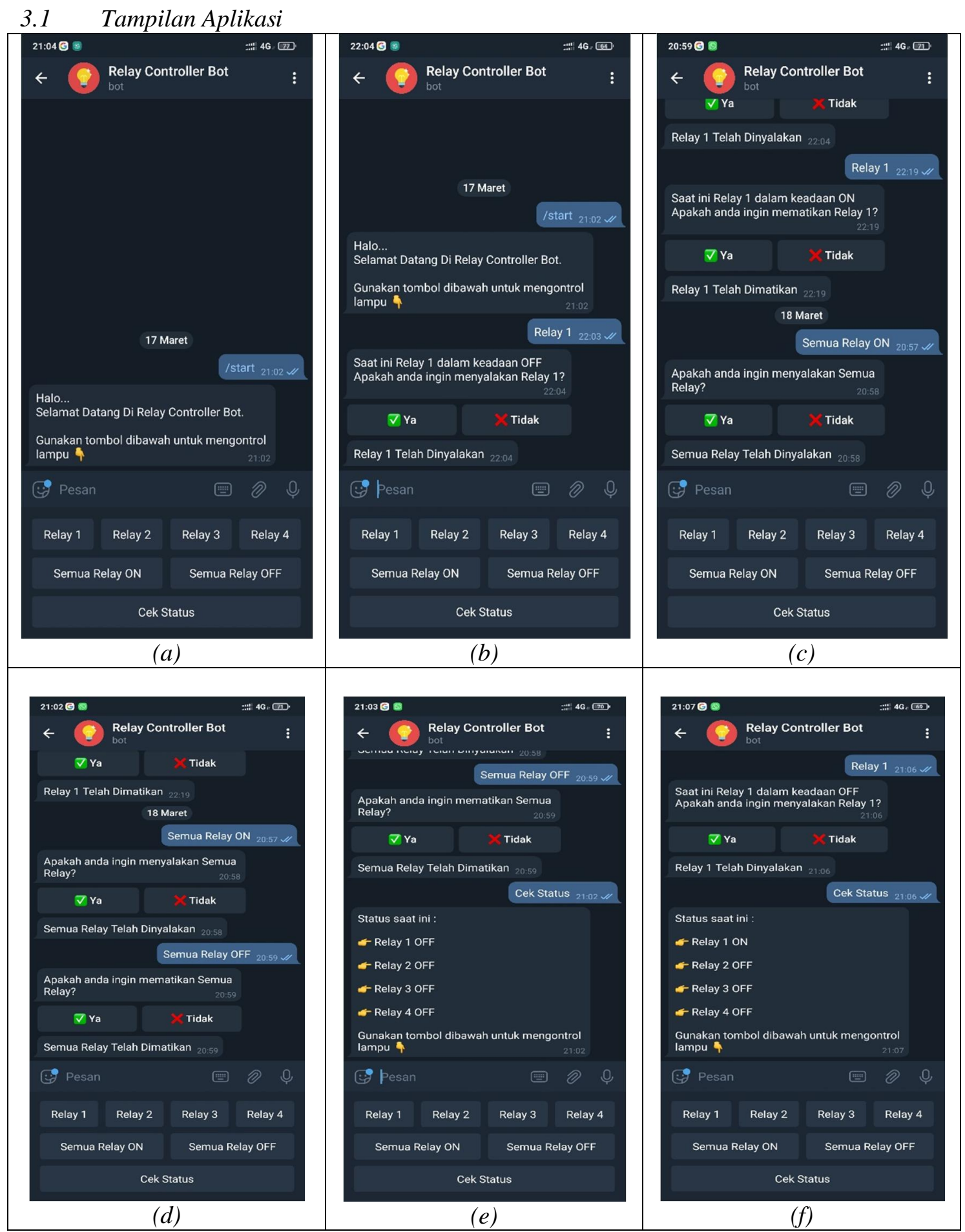

Gambar $a$ adalah tampilan awal utama bot Telegram yang nantinya akan digunakan sebagai sebagai controller perangkat elektronik. Di awal tampilan bot Telegram terdapat penjelasan nama dan petunjuk penggunaan bot. Kemudian terdapat 7 button virtual. Dalam controller bot ini dapat digunakan sampai 4 slot perangkat elektronik. 
Gambar $b$ adalah tampilan saat button relay dihidupkan dan ketika perangkat telah berhasil dihidupkan maka akan muncul keterangan bahwa relay telah berhasil dihidupkan. Dan switch relay akan mengalirkan aliran listrik ke perangkat elektronik sehingga lampu 1 akan menyala.

Gambar $c$ adalah button yang digunakan untuk menghidupkan semua perangkat elektronik secara bersamaan. Tampilan bot saat button "Semua Relay ON" ditekan dan mengirimkan perintah untuk menyalakan semua relay. Setelah berhasil mengirimkan perintah maka bot akan memberikan pesan balasan

Gambar $d$ adalah button yang berfungsi untuk mematikan semua relay secara bersamaan. Tampilan bot saat button "Semua Relay OFF" ditekan dan mengirimkan perintah untuk mematikan semua relay. Setelah berhasil mengirimkan perintah maka bot akan memberikan pesan balasan.

Gambar $e$ dan $f$ adalah tampilan ketika button "Cek Status" ditekan. Berisi tentang informasi relay mana yang aktif dan relay dan tidak aktif. Dalam hal ini dapat dimanfaatkan ketika user tidak sedang berada di dalam rumah sehingga user dapat mengontrol perangkat elektronik yang berada di rumah.

\subsection{Kode Program}

- Kode Program 1 connector bot dengan microcontroller

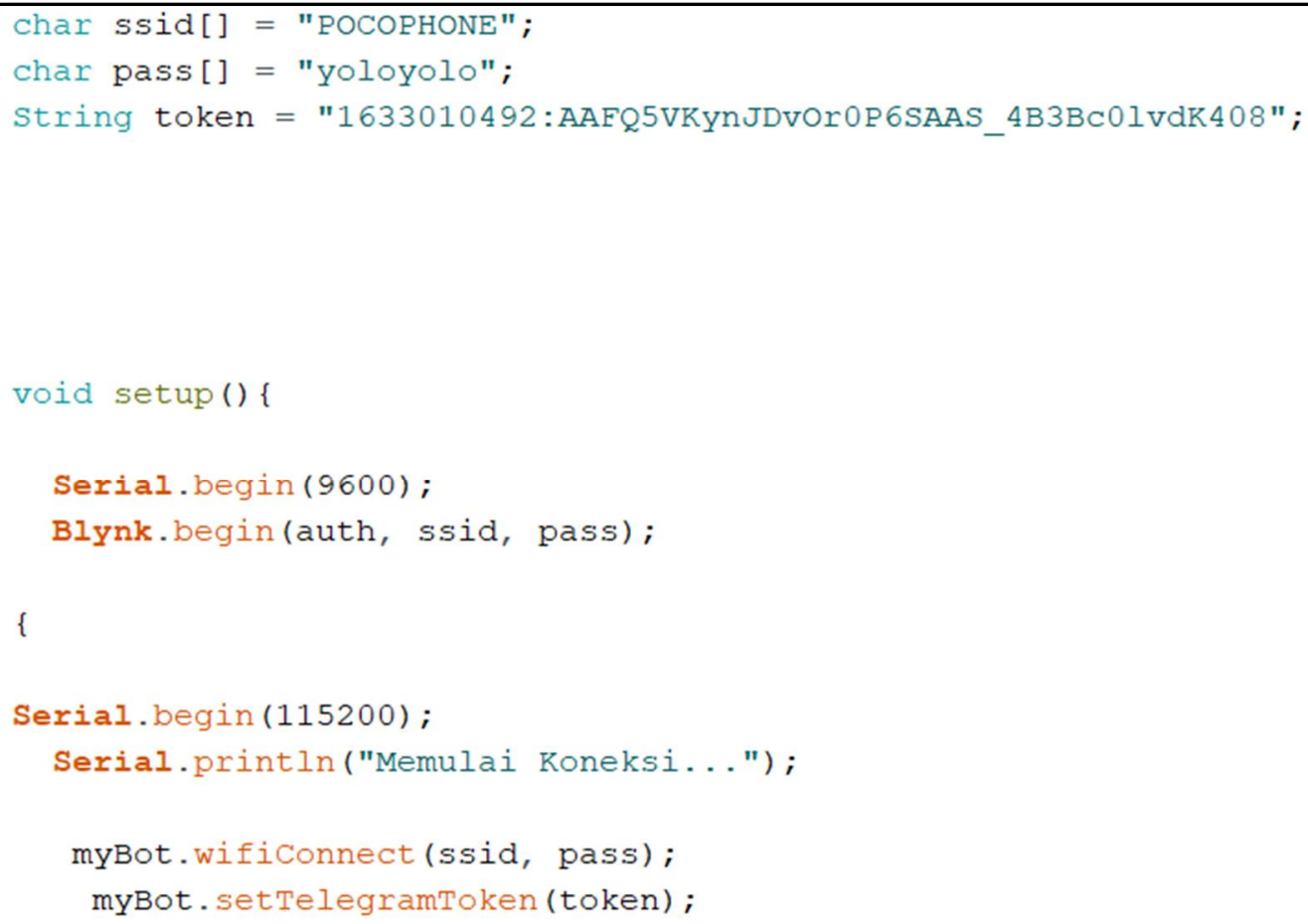

Gambar 4. Kode Program Connector

Untuk menyambungkan bot telegram ke microcontroller pertama kita merlu mendefinisikan ssid dan password dengan menggunakan tipe data char (character). Kemudian setelah kita definisikan ssid dan password kita masukan token untuk menghubungkan bot telegram ke microcontroller. Perintah mtBot.wifiConnect digunakan untuk mengkoneksikan bot dengan wifi perangkat. Sedangkan untuk perintah myBot.setTelegramToken digunakan untuk inisialisasi token untuk bot telegram yang sudah dibuat, dimana nantinya token ini sebagai identitas untuk menerima dan mengirim perintah dari telegram. 
- Kode Program 2 untuk mengaktifkan relay

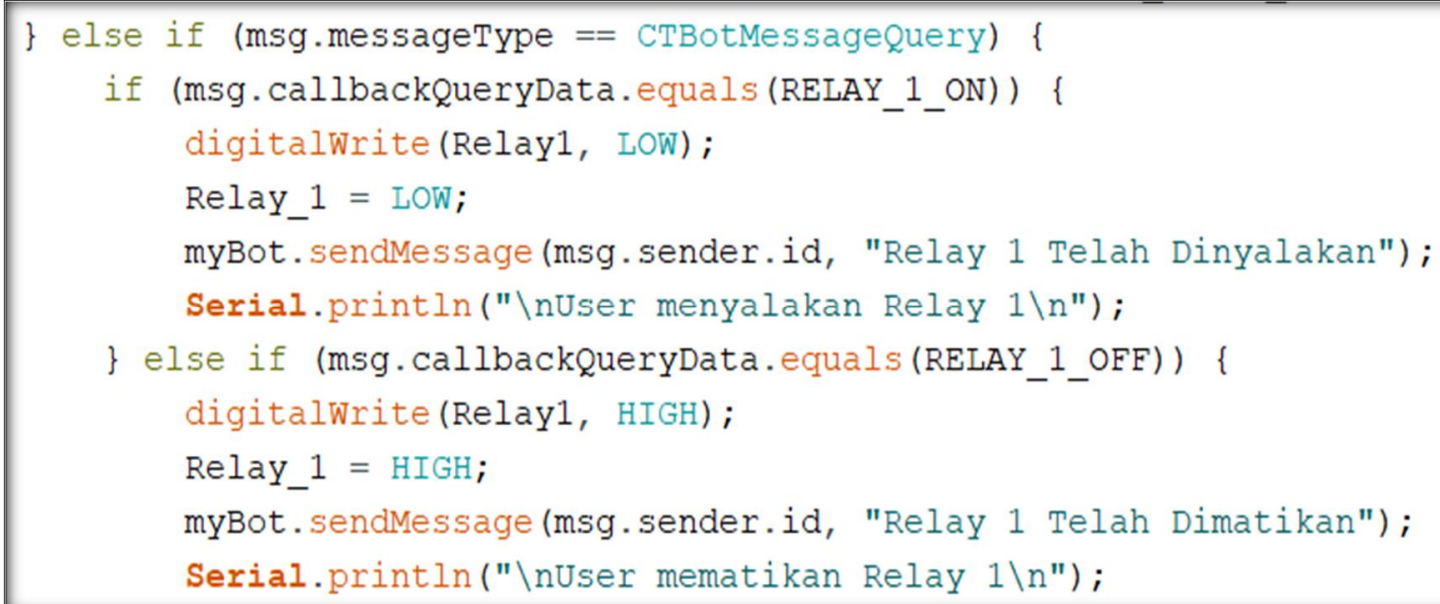

Gambar 5. Kode Program Aktifkan Relay

Kode program 2 adalah dimana saat user menekan button relay, maka relay akan mengirim perintah RELAY_1_ON, dimana RELAY_1_ON adalah variabel yang telah didefinisikan sebagai balasan dari button keyboard. Kemudian setelah perintah diterima relay akan berganti menjadi kondisi "LOW" (dikarenakan kita menggunakan relay model activelow yang dimana relay akan hidup jika diberi sinyal logika 0) dan perangkat akan aktif. Begitupun sebaliknya jika kondisi sebelumnya relay adalah "LOW" maka akan berganti menjadi "HIGH" dan perangkat menjadi tidak aktif.

- Kode Program 3 untuk mengirim informasi relay

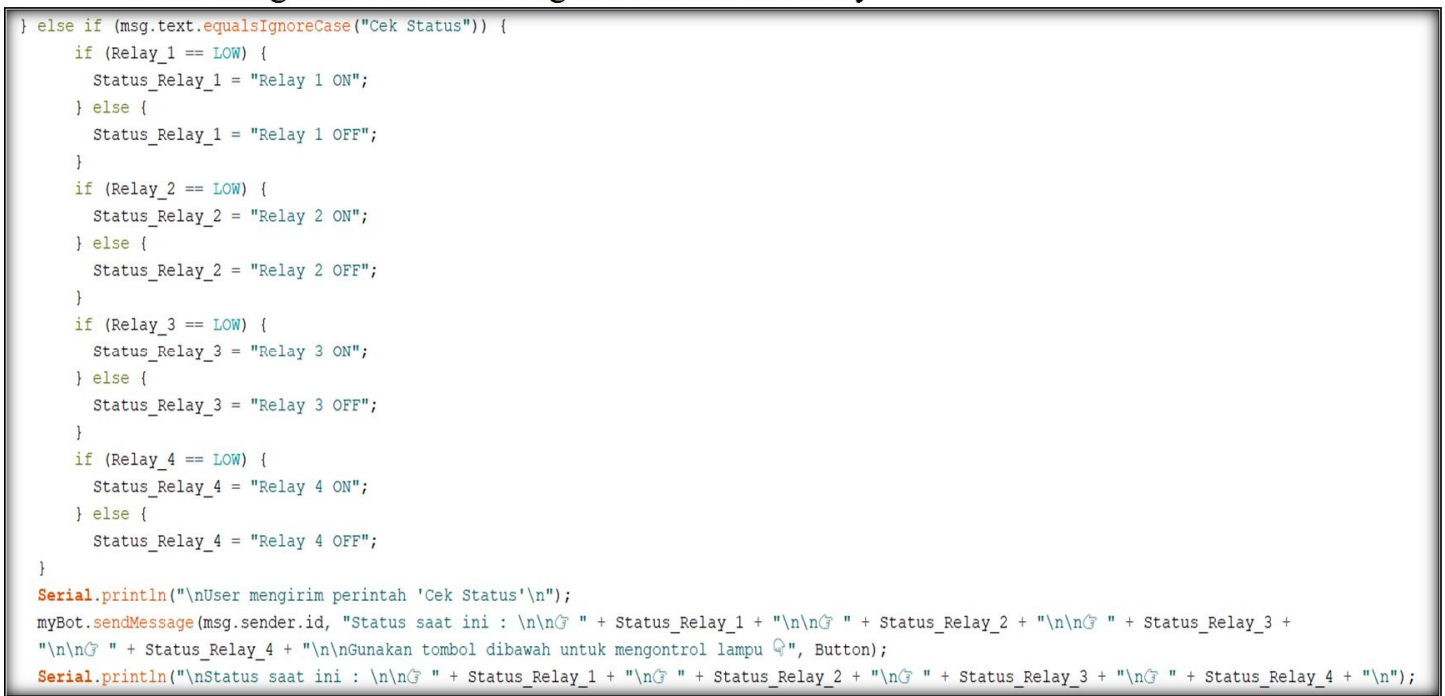

Gambar 6. Kode Program Informasi

Kode program 3 berisi tentang perintah bagaimana cara bot telegram mengirim informasi relay aktif. Disini terdapat kondisi dimana jika relay 1 bernilai "LOW" maka bot akan mengirimkan pesan "Relay 1 ON" dan jika kondisi relay 1 sebelumnya bernilai "HIGH" maka bot akan mengirimkan pesan "Relay 1 OFF". Kemudian perintah myBot.SendMessage akan mengirimkan pesan balasan keterangan informasi relay aktif dan non-aktif ke user. 


\subsection{Hasil Peracangan dan Pengujian}

Pengujian dilakukan berdasarkan perancangan yang telah dibuat untuk menguji kinerja dari fungsi-fungsi yang terdapat pada sistem apakah sudah sesuai atau belum.

- $\quad$ Pengujian 1 button Relay

Gambar 4 adalah kondisi lampu pada saat button relay ditekan.

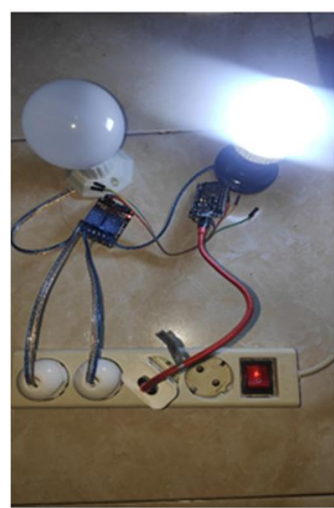

Gambar 7. Lampu 1 Menyala

- Pengujian 2 button Semua Relay ON

Gambar 5 adalah kondisi lampu pada saat button Semua Relay ON ditekan.

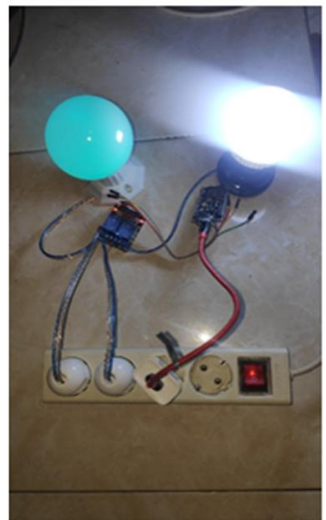

Gambar 8. Semua Lampu Menyala

- Pengujian 3 button Semua Relay OFF

Gambar 6 adalah kodisi lampu pada saat button Semua Relay OFF ditekan.

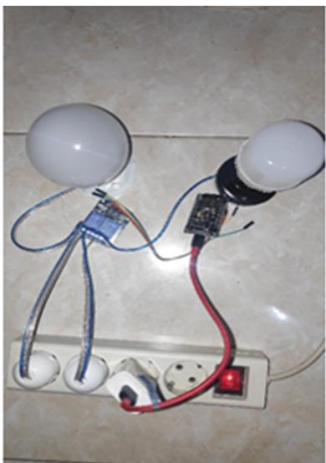

Gambar 9. Semua Lampu Mati 


\section{KESIMPULAN}

Berdasarkan dari penelitian yang telah dilakukan, maka dapat ditarik kesimpulan bahwa dengan dibangunnya controller kendali lampu ruangan berbasis IoT (Internet of Things) yang memanfaatkan smartphone Android dapat membantu masyarakat dalam mengendalikan perangkat elektronik terutama lampu jarak jauh, dimanapun, dan kapanpun, tanpa harus menuju sumber saklar. Sehingga user dapat mengontrol perangkat yang jauh dari lokasi terutama pada bangunan bertingkat yang tentunya membutuhkan banyak waktu dan tenaga.

\section{SARAN}

Saran untuk pengembangan penelitian selanjutnya adalah dapat diperluas dalam lingkup satu rumah dan berfokus pada peningkatan pengembangan fungsi sehingga tidak terbatas dalam satu lingkup ruangan.

\section{UCAPAN TERIMA KASIH}

Penulis mengucapkan banyak terima kasih kepada semua pihak yang telah berkontribusi memberikan dukungan baik secara langsung maupun dukungan secara tidak langsung yang tidak dapat disebutkan satu-persatu.

\section{DAFTAR PUSTAKA}

[1] D. Rahmawan Putra and A. Nugroho, "Pengembangan Game Edukatif Berbasis Android Sebagai Media Pembelajaran Akuntansi pada Materi Jurnal Penyesuaian Perusahan Jasa Developing Android Based Educational Game As A Means Of Accounting Learning On Service Company Adjusting Journal Material Oleh," J. Pendidik. Akunt. Indones., vol. XIV, No. 1, pp. 25-34, 2016, [Online]. Available: https://journal.uny.ac.id/index.php/jpakun/article/view/11364.

[2] P. Agung, A. Z. Iftikhor, D. Damayanti, and M. Bakri, "Sistem Rumah Cerdas Berbasis Internet of Things Dengan Mikrokontroler Nodemcu dan Aplikasi Telegram," J. Tek. dan Sist. Komput., Vol. 1, No. 1, pp. 8-14, 2020, doi: 10.33365/jtikom.v1i1.47.

[3] F. C. A. P. Surbakti, "Prototype Smart Home Berbasis IoT (Internet of Things)," Vol. 1, No. 2, pp. 6-38, 2001.

[4] P. Issn, "Internet Of Things (IOT) Sistem Pengendalian Lampu," Vol. 4, No. 1, pp. 1926, 2018.

[5] R. Muzawi and W. J. Kurniawan, "Penerapan Internet of Things (IoT) pada Sistem Kendali Lampu Berbasis Mobile,” No. 2, pp. 115-120, 2018.

[6] A. Microcontroller, “Jurnal Keteknikan dan Sains (JUTEKS) - LPPM UNHAS Vol. 1, No.1, Juni 2018, pp. 23-31, 2018.

[7] B. Artono and R. G. Putra, "Penerapan Internet of Things (Iot) Untuk Kontrol Lampu Menggunakan Arduino Berbasis,” No. April, pp. 8-16, 2019, doi: 10.25047/jtit.v5i1.73. 
[8] I. Warangkiran, I. S. T. G. Kaunang, A. S. M. Lumenta, and A. M. R. St, "Perancangan Kendali Lampu Berbasis Android,” Vol. 1, 2014.

[9] N. Hidayati et al., "Prototype Smart Home Dengan Modul Nodemcu esp8266 Berbasis Internet of Hings (iot)."

[10] A. I. Harsapranata, "Pengembangan Internet of Things yang Dimanfaatkan Dalam Monitoring Ruang Server,” Pros. Semin. Nas. Teknoka, Vol. 4, No. 2502, pp. I39-I43, 2019, doi: 10.22236/teknoka.v4i0.4194. 